Pak. J. Anal. Environ. Chem. Vol. 21, No. 1 (2020) 125 - 131

\title{
Evaluation of Antibacterial Activity of Zinc Oxide Nanoparticles and Acrylamide Composite Against Multidrug-Resistant Pathogenic Bacteria
}

\author{
Urooj Afreen, Shaista Bano*, Sarfraz Ali Tunio, Munazza Sharif \\ and Abdul Nabi Mirjat \\ Institute of Microbiology, University of Sindh, Jamshoro, Pakistan. \\ *Corresponding Author Email: shaista.bano@usindh.edu.pk \\ Received 23 December 2019, Revised 07 May 2020, Accepted 30 May 2020
}

\begin{abstract}
Emerging antibiotic resistance in pathogenic bacteria is creating serious crises in therapeutic options for treating infections worldwide. Thus, in the quest of alternative efficacious antibacterial therapy, various previous studies have demonstrated that the coating material used for the synthesis of Zinc oxide nanoparticles has tremendously improved the antibacterial activity of nanoparticles. The aim of current study was to investigate the antibacterial activities of Zinc oxide nanoparticles and acrylamide composite ( $\mathrm{ZnO}-\mathrm{Am}-\mathrm{NPs}$ ) against multidrug-resistant pathogenic bacteria. Isolation and identification was performed by using standard conventional and biochemical techniques. The antimicrobial activity of $\mathrm{ZnO}$-Am-NPs was determined by using modified agar well diffusion assay. The efficacy of ZnO-Am-NPs was compared with commercially available standard antibiotics discs. The data showed that ZnO-Am-NPs possessed strong antibacterial activity against multidrug-resistant pathogenic bacteria including Escherichia coli, Pseudomonas aeruginosa, Klebsiella pneumoniae, and Staphylococcus aureus, suggesting that coating of $\mathrm{ZnO}-\mathrm{NPs}$ with acrylamide resulted in the broad spectrum antibacterial activity. The antibacterial activity increased with the increasing concentration of $\mathrm{ZnO}$-Am-NPs whereas the minimum inhibitory concentration of $\mathrm{ZnO}-\mathrm{Am}-\mathrm{NPs}$ was recorded as $12.5 \mu \mathrm{g} / \mathrm{ml}$. The results of present study indicated that the $\mathrm{ZnO}$-Am-NPs may serve as promising antibacterial agents against multidrug resistant and medically important bacteria.
\end{abstract}

Keywords: Zinc oxide, Nanoparticles, Antibacterial activity, Broad spectrum, Acrylamide

\section{Introduction}

Zinc oxide $(\mathrm{ZnO})$ has been used as a suitable candidate for the synthesis of nanoparticles that are widely used in various industrial products including cosmetics [1]. In addition to many peculiar physical and chemical properties, $\mathrm{ZnO}$ nanoparticles (ZnO-NPs) have been shown to possess a number of dermatological and antibacterial properties [2]. $\mathrm{ZnO}-\mathrm{NPs}$ have been generally demonstrated to exhibit significant antibacterial properties when they were formed with sizes less than $100 \mathrm{~nm}$ [3]. The special characteristics such as large surface area and small particle size of $\mathrm{ZnO}-\mathrm{NPs}$, which are not present in micro or macro-sized particles of $\mathrm{ZnO}$ are attributed to their antibacterial activities. In nano size, $\mathrm{ZnO}$ can easily interact with bacterial surface getting entry inside the cell, and subsequently can exhibit a strong toxicity with the distinct bactericidal mechanisms [4]. Furthermore, $\mathrm{ZnO}$ NPs have been shown to exhibit lowest activity against human cells while possessing selective toxicity against bacterial cells, which is a fundamental property of any compound to be an ideal antibiotic [5-7]. Consequently, the effects of 
$\mathrm{ZnO}$ on bacteria in microscale and nanoscale formulations as an antimicrobial agent have been explored by various researchers from across the world [8-10]. The researchers have concluded that the nanoparticles have activity against a wide range of micro-organisms [11], fungi [12], fish [13], algae [14] and plants [15].

In the quest of alternative therapeutic agents for the treatment of bacterial infections caused by antibiotic resistant pathogens, the antibacterial activity of ZnO-NPs against Staphylococcus aureus [8], Escherichia coli [16], Campylobacter jejuni [9], Bacillus atrophaeus [17], ESBLs producing E. coli and Klebsiella pneumoniae [18], Haemophilus influenzae [19], and major food borne pathogens like E. coli O157:H7, Salmonella spp, Listeria monocytogenes $[2,20]$ has been determined. Reviewed literature has indicated that the material used for the synthesis of ZnO-NPs has dramatic effects on their antibacterial properties [21, 22]. Recently, improved antibacterial activity of ZnO-NPs against food borne and oral pathogens, with the use of different methods of their synthesis has been reported [23-25]. Therefore, the present study was carried out to determine the antibacterial activity of Zinc oxide nanoparticles and acrylamide composite ( $\mathrm{ZnO}-\mathrm{Am}-\mathrm{NPs}$ ) against a wide range of multidrug-resistant (MDR) pathogenic bacteria. Furthermore, ZnO-Am-NPs were also tested for their potential to be an antibacterial agent against pathogenic bacteria isolated from the patients with Device Associated Infections (DAI).

\section{Materials and Methods}

The present study was approved from the Advanced Studies and Research Board (ASRB), University of Sindh, Jamshoro. Clinical isolates were obtained from the diagnostic laboratories located at Hyderabad and their further identification and characterization was carried out at Clinical and Molecular Research Laboratory, Institute of Microbiology, University of Sindh, Jamshoro. For the isolation of pathogenic bacteria from DAI, a verbal consent was obtained from the patients with DAI, prior to the collection of sample. The samples were collected by the trained staff during the washing process of an infected implanted orthopedic device.

\section{Bacterial strains, media and growth conditions}

The bacterial strains used in the present study, S. aureus, E. coli, $P$. aeruginosa, $P$, fluorescens, $K$. pneumoniae, were previously isolated from clinical samples such as pus and urine samples. Bacterial cultures were grown aerobically at $37^{\circ} \mathrm{C}$ for $24 \mathrm{~h}$. All the media used in the present study, Muller Hinton agar, Eosine Methylene Blue agar, Nutrient agar and broth, MacConkey's agar, were purchased from Oxoid, UK.

\section{Isolation, identification and MDR pattern of pathogenic bacteria}

The isolation of pathogenic bacteria from different clinical samples was previously done using selective and differential media. Initial identification was done using standard biochemical tests. The multiple drug resistance (MDR) patterns were determined by using Kirby Baur disk diffusion assay with commercially available antibiotic discs according to CLSI (2006) guidelines and Zone of inhibition around an antibiotic disc was measured and compared with "Disc diffusion supplement table" [26]. The antibiotic discs used in the present study included: Ampicillin (AMP, 10 $\mu$ g), Aztreonam (ATM, 30 $\mu$ g), Ceftriaxone (CRO, 30 $\mu$ g), Cefuroxime (CXM, 30 $\mu \mathrm{g})$, Ceftazidime (CAZ, $30 \mu \mathrm{g}$ ), Cotrimoxazole (SXT, 1.25/23.75 $\mu \mathrm{g})$, Clindamycicn $(\mathrm{CD}, 2 \mu \mathrm{g})$ Erythromycin (E, $15 \mu \mathrm{g})$, Fusidic acid (FD, $10 \mu \mathrm{g})$, Gentamicin (CN, $10 \mu \mathrm{g}$ ), Ofloxacin (OFX, $5 \mu \mathrm{g}$ ), Oxacilin (OX, $5 \mu \mathrm{g}$ ) Piperacillin/Tazobactam (TZP, 100/10 $\mu \mathrm{g})$, Tetracycline (TE, 30 $\mu \mathrm{g}$ ), Vancomycin (VA, $30 \mu \mathrm{g}$ ).

\section{Synthesis of ZnO-Am-NPs}

The synthesis of $\mathrm{ZnO}-\mathrm{Am}-\mathrm{NPs}$ has been described previously [27]. Briefly, zinc acetate dihydrate; $\mathrm{Zn}\left(\mathrm{CH}_{3} \mathrm{CO}_{2}\right)_{2} \cdot 2 \mathrm{H}_{2} \mathrm{O}$, was prepared in a volume of $100 \mathrm{~mL}$, by using ammonia $\left(\mathrm{NH}_{3}\right)$ as $\mathrm{OH}$ ion source followed by the addition of 
acrylamide $\left(\mathrm{CH}_{2}=\mathrm{CHCNH}_{2}\right)$ that was dissolved in the solution and the beaker was coated with aluminum foil. The growth solution was kept at $95^{\circ} \mathrm{C}$ for $4 \mathrm{~h}$. After the completion of growth, $\mathrm{ZnO}$ functionalized acrylamide was collected by filtration and the final product was washed several times with deionized water and ethanol $\left(\mathrm{C}_{2} \mathrm{H}_{5} \mathrm{OH}\right)$. Then $\mathrm{ZnO}$ nanomaterial was dried at room temperature.

\section{Determination of the antibacterial activity of ZnO-Am-NPs}

The antibacterial activities of $\mathrm{ZnO}-\mathrm{Am}$ NPs were tested by agar well diffusion assay against different pathogenic bacteria $(n=14)$. Briefly, a sterile cotton swab was dipped in an overnight bacterial culture and spread over the surface of Mueller-Hinton agar plate to grow a thin lawn of the bacteria. Then, using a sterile cork borer, 6-mm wells were prepared aseptically. Twenty mg of synthesized material (dry ZnO-AmNPs) was added to $100 \mathrm{~mL}$ sterile distilled water and mixed vigorously by placing in an ultra sonicator for 30 minutes. The $\mathrm{ZnO}-\mathrm{Am}-\mathrm{NPs}$ solution of $20 \mathrm{mg} / 100 \mathrm{~mL}$ stock solution was prepared. Later, three different final concentrations of $\mathrm{ZnO}-\mathrm{Am}-\mathrm{NPs}(10,20$, and 40 $\mu \mathrm{g})$ were filled into the wells. The plates were left for $1 \mathrm{~h}$ to allow the perfusion of $\mathrm{ZnO}-\mathrm{Am}-\mathrm{NPs}$ which was followed by incubation at $37^{\circ} \mathrm{C}$ for $24 \mathrm{~h}$. Next day, the plates were observed for a zone of inhibition around each well which was measured in terms of diameter.

\section{Minimum inhibitory concentration of ZnO-Am- NPS}

The minimum inhibitory concentration (MIC) of $\mathrm{ZnO}-\mathrm{Am}-\mathrm{NPs}$ was determined by broth dilution method as described previously [28]. Briefly, a single colony of a bacterial culture was transferred to $5 \mathrm{~mL}$ of nutrient broth and incubated overnight at $37^{\circ} \mathrm{C}$. Next day, the tubes containing a defined concentration of $\mathrm{ZnO}-\mathrm{Am}-\mathrm{NPs}$ in the fresh nutrient broth were inoculated with the overnight culture. Turbidity was assessed after incubation for at least $16 \mathrm{~h}$ and the MIC readings/values were recorded.
Minimum bactericidal concentration of $\mathrm{ZnO}$ $A m-N P s$

The minimum bactericidal concentration (MBC) of $\mathrm{ZnO}-\mathrm{Am}-\mathrm{NPs}$ was determined by broth dilution followed by agar plate method. Briefly, a single colony of a bacterial culture (MDR pathogenic bacteria) was inoculated into $5 \mathrm{~mL}$ of nutrient broth and incubated for at least $16 \mathrm{~h}$ at $37^{\circ} \mathrm{C}$. Next day, the tubes containing fresh nutrient broth and a defined concentration of ZnO-Am-NPs were inoculated with the overnight culture. After incubation for at least $16 \mathrm{~h}, 50 \mu \mathrm{L}$ of culture from the tubes with no visible growth were inoculated onto fresh agar plates. Next day, the lowest concentration of $\mathrm{ZnO}-\mathrm{Am}-\mathrm{NPs}$, corresponding to culture revealing no $\mathrm{CFU}$ on plate, was considered as the MBC of $\mathrm{ZnO}-\mathrm{Am}-\mathrm{NPs}$.

\section{Results and Discussion \\ ZnO-NPs and acrylamide composite}

The acrylamide was used to increase the surface area of ZnO NPs which can be beneficial for enhancing antibacterial and antifungal properties. The synthesis and characterization of ZnO-Am-NPs (Fig. 1) by X-ray diffraction (XRD), Fourier transform infrared spectroscopy (FTIR), thermal-gravimeteric analysis (TGA), scanning gel electron microscope (SEM) and field emission electron microscope (FESEM) has been reported previously [27].

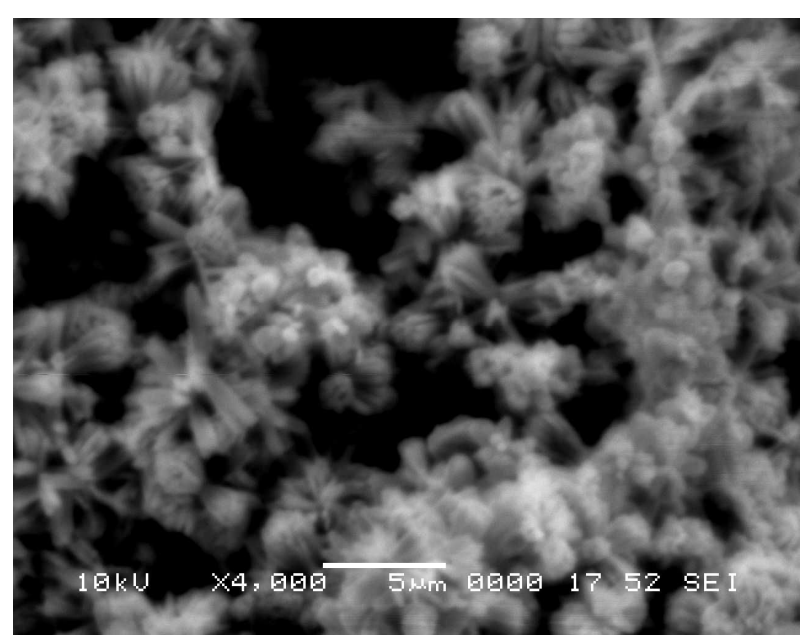

Figure 1. SEM of the nanoparticles of zinc oxide and acrylamide composite ( $\mathrm{ZnO}-\mathrm{Am}-\mathrm{NPs}$ ) 
Antibiotic resistance patterns of the pathogenic bacteria

The antibiotic resistance patterns of various pathogenic bacteria were determined. Nine bacterial strains (Fig. 2) showing MDR phenotypes were selected. These included $S$. aureus $(\mathrm{n}=03), E$. coli $(\mathrm{n}=03), K$. pneumoniae $(\mathrm{n}=01), P$. aeruginosa $(\mathrm{n}=01)$, and $P$. fluorescense $(\mathrm{n}=01)$. Moreover, five highly resistant Gramnegative pathogenic bacteria isolated from DAI were also selected for the present study. The DAI associated pathogenic bacteria included $P$. aeruginosa, S. epidermidis, Enterobacter sp, Citrobacter freundii, and Proteus sp. The MDR patterns of these pathogenic bacteria showed their resistance to at least five antibiotics used in the present study (Table 1).
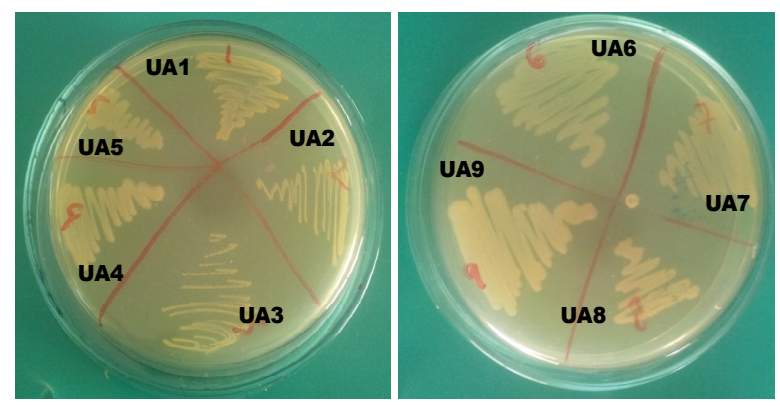

Figure 2. Pure cultures of the selected MDR pathogenic bacteria on nutrient agar. S. aureus (UA1-3), E. coli (UA4-6), P. aeruginosa (UA7), P. florescens (UA8) and K. pneumoniae (UA9)

Table 1. Antibiotic sensitivity profile and MDR patterns of bacterial isolates.

\begin{tabular}{|c|c|c|c|c|c|c|c|c|c|c|c|c|c|c|c|c|c|c|c|}
\hline \multirow{3}{*}{ Bacteria } & \multirow{3}{*}{ Specimen } & \multicolumn{17}{|c|}{ Antibiotics } & \multirow[b]{2}{*}{ MDR pattern } \\
\hline & & 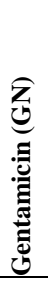 & 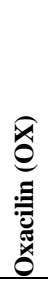 & 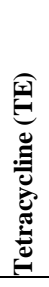 & 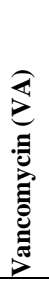 & 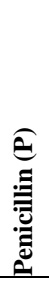 & 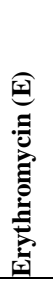 & 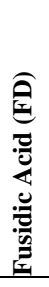 & 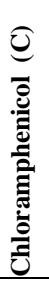 & 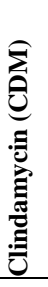 & 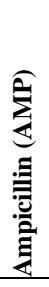 & 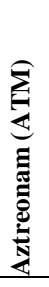 & 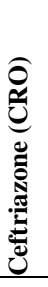 & 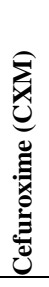 & 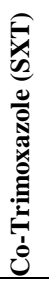 & 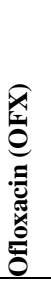 & 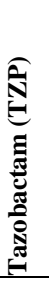 & 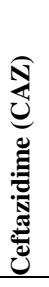 & \\
\hline & & & & & & & & & & & & & & & & & & & No. of Antibiotics \\
\hline S. aureus & Pus & $S$ & $\mathrm{R}$ & $S$ & $\mathrm{~S}$ & $\mathrm{R}$ & $\mathrm{R}$ & $\mathrm{S}$ & $\mathrm{S}$ & $S$ & $\mathrm{R}$ & - & $\mathrm{R}$ & - & $\mathrm{S}$ & - & - & - & 05 \\
\hline S. aureus & Pus & $S$ & $\mathrm{R}$ & $S$ & $\mathrm{~S}$ & $\mathrm{R}$ & $\mathrm{S}$ & $\mathrm{R}$ & $\mathrm{S}$ & S & $\mathrm{R}$ & - & $\mathrm{R}$ & - & $\mathrm{R}$ & - & - & - & 06 \\
\hline S. aureus & Pus & $S$ & $\mathrm{R}$ & $S$ & $S$ & $\mathrm{R}$ & S & $\mathrm{S}$ & $\mathrm{S}$ & S & $\mathrm{R}$ & - & $\mathrm{R}$ & - & $\mathrm{R}$ & - & - & - & 05 \\
\hline E. coli & Urine & $\mathrm{R}$ & - & $S$ & - & $\mathrm{R}$ & S & - & $\mathrm{S}$ & - & $\mathrm{R}$ & $\mathrm{S}$ & $\mathrm{R}$ & $\mathrm{R}$ & $\mathrm{R}$ & $\mathrm{R}$ & $S$ & $\mathrm{R}$ & 08 \\
\hline E. coli & Urine & $\mathrm{S}$ & - & $\mathrm{S}$ & - & $\mathrm{R}$ & $S$ & - & $\mathrm{S}$ & - & $\mathrm{R}$ & $\mathrm{R}$ & $\mathrm{R}$ & $S$ & $\mathrm{R}$ & $\mathrm{R}$ & $\mathrm{S}$ & $\mathrm{R}$ & 07 \\
\hline E. coli & Urine & $\mathrm{R}$ & - & $\mathrm{S}$ & - & $\mathrm{R}$ & S & - & $\mathrm{S}$ & - & $\mathrm{R}$ & $\mathrm{R}$ & $\mathrm{R}$ & $\mathrm{R}$ & $\mathrm{R}$ & $\mathrm{R}$ & $\mathrm{S}$ & $\mathrm{R}$ & 09 \\
\hline P. aeruginosa & Pus & $\mathrm{R}$ & - & $S$ & - & $\mathrm{R}$ & $\mathrm{R}$ & - & $\mathrm{S}$ & - & $\mathrm{R}$ & S & $\mathrm{R}$ & S & $\mathrm{R}$ & $\mathrm{R}$ & S & $S$ & 07 \\
\hline P. fluorescens & Urine & $\mathrm{S}$ & - & $S$ & - & $\mathrm{R}$ & $\mathrm{R}$ & - & $\mathrm{S}$ & - & I & $\mathrm{R}$ & $\mathrm{R}$ & $\mathrm{R}$ & $\mathrm{R}$ & $\mathrm{R}$ & $S$ & $S$ & 07 \\
\hline K. pneumoniae & $\mathrm{WT}^{*}$ & S & - & $\mathrm{S}$ & - & $\mathrm{R}$ & S & - & S & - & $\mathrm{R}$ & $\mathrm{R}$ & $\mathrm{R}$ & - & $\mathrm{R}$ & $\mathrm{S}$ & $\mathrm{S}$ & $\mathrm{S}$ & 05 \\
\hline S. epidermidis & DAI & S & $\mathrm{R}$ & $\mathrm{R}$ & S & $\mathrm{R}$ & $\mathrm{R}$ & $\mathrm{R}$ & S & S & $\mathrm{R}$ & - & $\mathrm{R}$ & - & $\mathrm{R}$ & - & - & - & 08 \\
\hline P. aeruginosa & DAI & $\mathrm{S}$ & - & $\mathrm{S}$ & & $\mathrm{R}$ & $\mathrm{R}$ & - & $\mathrm{S}$ & - & $\mathrm{R}$ & $\mathrm{R}$ & $\mathrm{R}$ & - & $\mathrm{R}$ & $\mathrm{R}$ & - & $\mathrm{R}$ & 08 \\
\hline Enterobacter spp & DAI & $\mathrm{R}$ & - & $\mathrm{R}$ & & $\mathrm{R}$ & - & - & $\mathrm{S}$ & - & $\mathrm{R}$ & $\mathrm{R}$ & $\mathrm{R}$ & - & $\mathrm{S}$ & $\mathrm{S}$ & - & $\mathrm{R}$ & 07 \\
\hline Citrobacter freundii & DAI & $\mathrm{S}$ & $\mathrm{R}$ & & & $\mathrm{R}$ & - & - & $\mathrm{S}$ & -- & $\mathrm{R}$ & $\mathrm{S}$ & $\mathrm{R}$ & - & $\mathrm{S}$ & $\mathrm{R}$ & - & $\mathrm{R}$ & 06 \\
\hline Proteus spp & DAI & $\mathrm{S}$ & - & & & $\mathrm{R}$ & - & - & $\mathrm{S}$ & & $\mathrm{R}$ & $\mathrm{S}$ & $\mathrm{R}$ & - & $\mathrm{R}$ & $\mathrm{R}$ & - & $\mathrm{R}$ & 06 \\
\hline
\end{tabular}


Antibacterial effects of ZnO-Am-NPs against MDR pathogenic bacteria

In recent years, a striking inclination in the rate of resistance in pathogenic bacteria against the available therapeutic options has caused a serious health problem [29]. Therefore, researchers are focusing on the identification and development of alternative therapeutic approaches. Among the some alternative therapeutic agents, metal and metal oxide nanoparticles have recently been at the main focus of investigations [30-32]. In the present study, we focused on the determination of the antibacterial effects of $\mathrm{ZnO}-\mathrm{Am}-\mathrm{NPs}$ against a wide range of pathogenic bacteria that are listed in Table 2. $\mathrm{ZnO}-\mathrm{Am}-\mathrm{NPs}$ showed strong activity against $S$. aureus isolates of pus specimens (Table 2).

Table 2. Antibacterial effects of $\mathrm{ZnO}$-Am-NPs against MDR pathogenic bacteria.

\begin{tabular}{|c|c|}
\hline Bacterial isolates & $\begin{array}{l}\text { Size of inhibition zones (mm) } \\
20 \mu \mathrm{g} / 100 \mu \mathrm{L} \text { of } \mathrm{ZnO}-\mathrm{Am}-\mathrm{NPs}\end{array}$ \\
\hline S. aureus & $34.16 \pm 0.087$ \\
\hline S. aureus & $33.83 \pm 0.174$ \\
\hline S. aureus & $34.0 \pm 0.0$ \\
\hline E. coli & $32.66 \pm 0.174$ \\
\hline E. coli & $33.0 \pm 0.0$ \\
\hline E. coli & $33.0 \pm 0.0$ \\
\hline P. aeruginosa & $33.0 \pm 0.0$ \\
\hline P. fluorescens & $33.50 \pm 0.150$ \\
\hline K. pneumoniae & $30.16 \pm 0.087$ \\
\hline S. epidermidis (DAI) & $29.0 \pm 0.0$ \\
\hline P. aeruginosa (DAI) & $30.16 \pm 0.087$ \\
\hline Enterobacter spp (DAI) & $27.0 \pm 0.0$ \\
\hline Citrobacter freundii (DAI) & $22.33 \pm 0.174$ \\
\hline Proteus spp (DAI) & $29.0 \pm 0.30$ \\
\hline
\end{tabular}

Data are means of three replicates \pm standard error.

These findings support the fact of including $\mathrm{ZnO}$ in various dermatological applications such as creams, lotions and ointments [33]. Similar findings were also observed against the E. coli isolates of urine specimens. Furthermore, it was noted that the size of the zones of inhibition against the isolates of DAI were comparatively smaller in size. In order to compare the antibacterial effects of ZnO-Am-NPs with commercially available antibiotics, last resort antibiotic for each of the clinical isolate of the present study was used. For instance, $S$. epidermidis isolated from DAI specimen was resistant to the majority of antibiotics tested while showing sensitivity to FD and CDM antibiotics. Therefore, the commercially available disc of FD was used along with a disc impregnated with $\mathrm{ZnO}$ Am-NPs. Similar protocol was used for all other clinical isolates. It was observed that the size of zones of inhibition obtained from $20 \mu \mathrm{g} / 100 \mu \mathrm{L}$ of $\mathrm{ZnO}-\mathrm{Am}-\mathrm{NPs}$ against each of the tested bacteria was comparable to that of achieved from the last resort antibiotic.

\section{Minimum inhibitory and bactericidal concentration of ZnO-Am-NPs}

MIC is defined as the lowest concentration of an antimicrobial agent that inhibits the microbial growth while MBC is the lowest concentration of an antimicrobial agent that kills the microbial cells after $24 \mathrm{~h}$ of exposure. The MIC and MBC of ZnO-Am-NPs against MDR pathogenic bacteria was between $12.5 \mu \mathrm{g} / \mathrm{ml}$ to 25 $\mu \mathrm{g} / \mathrm{mL}$, and $25 \mu \mathrm{g} / \mathrm{mL}$ to $50 \mu \mathrm{g} / \mathrm{mL}$, respectively (Fig. 3).

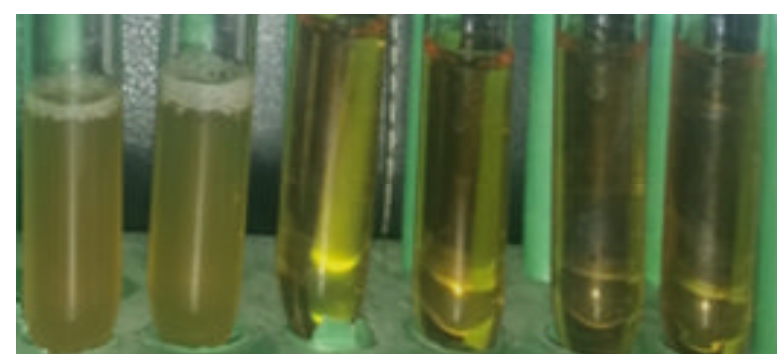

Figure 3. Representative result of the determination of MIC of ZnO-Am-NPs against MDR pathogenic bacteria

\section{Conclusion}

The $\mathrm{ZnO}-\mathrm{Am}-\mathrm{NPs}$ were effective against the pathogenic bacteria isolated from pus and urine specimens suggesting that the material used for making the composite of $\mathrm{ZnO}-\mathrm{NPs}$, "acrylamide" has potential to enhance the antibacterial properties of $\mathrm{ZnO}-\mathrm{NPs}$. Given the findings of the present study, it was concluded that the ZnO-Am-NPs composite hold broad spectrum activity and could be useful in future strategies for the development of an alternative antimicrobial to combat some common MDR pathogenic bacteria. 
Having antagonistic effects on the MDR pathogenic bacteria, $\mathrm{ZnO}-\mathrm{Am}-\mathrm{NPs}$ provide an absolutely attractive option for the treatment of different "difficult to treat" infections. Furthermore, the MIC of ZnO-Am-NPs $(12.5 \mu \mathrm{g} / \mathrm{ml})$ is very low and represents the potential of $\mathrm{ZnO}$-Am-NPs to appear as a less costly antimicrobial agent in the future.

\section{Acknowledgement}

Authors are thankful to Dr. Zafar Hussain Ibupoto, Associate Professor, Institute of Chemistry, University of Sindh, for providing the synthesized ZnO-Am-NPs. Authors are also thankful to the management of various diagnostic laboratories and hospitals for facilitating us in the collection of clinical samples.

\section{Conflict of interest}

Authors declare "no conflict of interest".

\section{References}

1. L. M. Katz, K. Dewan and R. L. Bronaugh, Food Chem. Toxicol., 85 (2015) 127. doi:https://doi.org/10.1016/j.fct.2015.06.020.

2. Y. Liu, L. He, A. Mustapha, H. Li, Z. Hu and M. Lin, J. Appl. Microbiol., 107 (2009) 1193.

doi:https://doi.org/10.1111/j.13652672.2009.04303.x.

3. K. R. Raghupathi, R. T. Koodali and A. C. Manna, Langmuir, 27 (2011) 4020. doi: 10.1021/la104825u.

4. J. T. Seil and T. J. Webster, Int. J. Nanomed., 7 (2012) 2767.

doi: https://doi.org/10.2147/ijn.s24805.

5. R. Brayner, R. Ferrari-Iliou, N. Brivois, S. Djediat, M. F. Benedetti and F. Fiévet, Nano Lett., 6 (2006) 866. doi: https://doi.org/10.1021/n1052326h.

6. M. Reddy, T. Yu, C.-H. Sow, Z. X. Shen, C. T. Lim, G. Subba Rao and B. Chowdari, Adv. Functional Materials. 17 (2007) 2792. doi:https://doi.org/10.1002/adfm.200601186.

7. A. Thill, O. Zeyons, O. Spalla, F. Chauvat, J. Rose, M. Auffan and A. M. Flank, Environ. Sci. Technol., 40 (2006) 6151. doi: https://doi.org/10.1021/es060999b.
8. N. Jones, B. Ray, K. T. Ranjit and A. C. Manna, FEMS Microbiol. Lett., 279 (2008) 71. doi:https://doi.org/10.1111/j.15746968.2007.01012.x.

9. Y. Xie, Y. He, P. L. Irwin, T. Jin, X. Shi, Appl. Environ. Microbiol., 77 (2011) 2325. doi: https://doi.org/10.1128/aem.02149-10.

10. U. Kadiyala, E. S. Tulari-Emre, J. H. Bahng, N. A. Kotov and J. S. Van Epps, Nanoscale. (2018).

doi: https://doi.org/10.1039/ c7nr08499d.

11. A. M. Allahverdiyev, K. V. Kon, E. S. Abamor, M. Bagirova, M. Rafailovich, Expert. Rev. Anti. Infect. Ther., 9 (2011) 1035.

doi: https://doi.org/10.1586/eri.11.121.

12. Z. Huang, X. Zheng, D. Yan, G. Yin, X. Liao, Y. Kang, Y. Yao, D. Huang and B. Hao, Langmuir, 24 (2008) 4140. doi: 10.1021/la7035949.

13. L. He, Y. Liu, A. Mustapha and M. Lin, Microbiol. Res., 166 (2011) 207. doi: 10.1016/j.micres.2010.03.003.

14. Lin., Y. Zhao, T. Xia, H. Meng, Z. Ji, R. Liu, S. George, S. Xiong, X. Wang, H. Zhang, S. Pokhrel, L. Madler, R. Damoiseaux, S. Lin and A. E. Nel, ACS Nano, 5 (2011) 7284. doi: $10.1021 / \mathrm{nn} 202116 \mathrm{p}$.

15. S. W. Wong, P. T. Leung, A. B. Djurisic and K. M. Leung, Anal. Bioanal. Chem., 396 (2010) 609.

doi: 10.1007/s00216-009-3249-z.

16. Z. Emami-Karvani and P. Chehrazi, Afr. J. Microbiol. Res., 5 (2011) 1368.

doi: 10.5897/AJMR10.159.

17. K. Tam, A. Djurišić, C. Chan, Y. Xi, C. Tse, Y. Leung, W. Chan, F. Leung and D. Au, Thin Solid Films., 516 (2008) 6167. doi:https://doi.org/10.1016/j.tsf.2007.11.081.

18. A. S. H. Hameed, C. Karthikeyan, A. P. Ahamed, N. Thajuddin, N. S. Alharbi, S. A. Alharbi and G. Ravi, Sci. Rep., 6 (2016) 24312. doi: https://doi.org/10.1038/srep24312.

19. P. Surwade, T. Luxton, J. Clar, F. Xin and V. Shah, J. Nanoparticle Res., 22 (2020) 43. doi:https://doi.org/10.1007/s11051-0204767-z. 
20. M. Brust, M. Walker, D. Bethell, D. J. Schiffrin and R. Whyman, Chem. Commun. (1994) 801. doi: 10.1039/C39940000801.

21. J. Iqbal, T. Jan, M. Ismail, N. Ahmad, A. Arif, M. Khan, M. Adil and A. Arshad, Ceramics Int., 40 (2014) 7487. doi:doi.org/10.1016/j.ceramint.2013.12.099.

22. J. I. Tariq Jan, M. Ismail, M. Zakaullah, S. H. Naqvi and N. Badshah, Int. J. Nanomed., 8 (2013) 3679. doi: https://doi.org/10.2147/ijn.s45439.

23. R. C. D. Souza, L. U. Haberbeck, H. G. Riella, D. H. Ribeiro and B. A. Carciofi, Braz. J. Chem. Eng., 36 (2019) 885. doi:http://dx.doi.org/10.1590/01046632.20190362s20180027

24. A. M. Awwad, M. W. Amer, N. M. Salem and A. O. Abdeen, Chem. Int., 6 (2020) 151. doi:https://doi.org/10.5281/zenodo.3559520.

25. M. Srinisha, S. Rajeshkumar, T. Lakshmi and A. Roy, Int. J. Res. Pharmaceut. Sci., 10 (2019) 2826. doi:https://doi.org/10.26452/ijrps.v10i4.155 $\underline{4}$.

26. P. Wayne, Twentieth Informational Supplement., 30 (2010) M100.

27. A. Aftab, A. Ismail, S. Khokhar, Z. H. Ibupoto, J. Petrol Sci. Eng., 146 (2016) 1142.

doi:https://doi.org/10.1016/j.petrol.2016.08. $\underline{014}$.
28. J. M. Andrews, J. Antimicrob. Chemoth., 48 (2001) 5 . doi: 10.1093/jac/48.suppl 1.5 .

29. B. Aslam, W. Wang, M. I. Arshad, M. Khurshid, S. Muzammil, M. H. Rasool, M. A. Nisar, R. F. Alvi, M. A. Aslam, M. U. Qamar, M. K. F. Salamat and Z. Baloch, Infect. Drug Resist., 11 (2018) 1645. doi: 10.2147/IDR.S173867.

30. G. R. Rodrigues, C. Lopez-Abarrategui, I. de la Serna Gomez, S. C. Dias, A. J. OteroGonzalez and O. L. Franco, Int. J. Pharm., 555 (2019) 356. doi: 10.1016/j.ijpharm.2018.11.043.

31. K. Gold, B. Slay, M. Knackstedt and A. K. Gaharwar, Adv. Ther., 1 (2018) 1700033. doi:https://doi.org/10.1002/adtp.201700033.

32. P. Lv, L. Zhu, Y. Yu, W. Wang, G. Liu and H. Lu, Mater. Sci. Eng. C, (2020) 110669. doi:https://doi.org/10.1016/j.msec.2020.110 669.

33. J. Sawai J. Microbiol. Methods, 54 (2003) 177.

doi:https://doi.org/10.1016/s01677012(03)00037-x. 